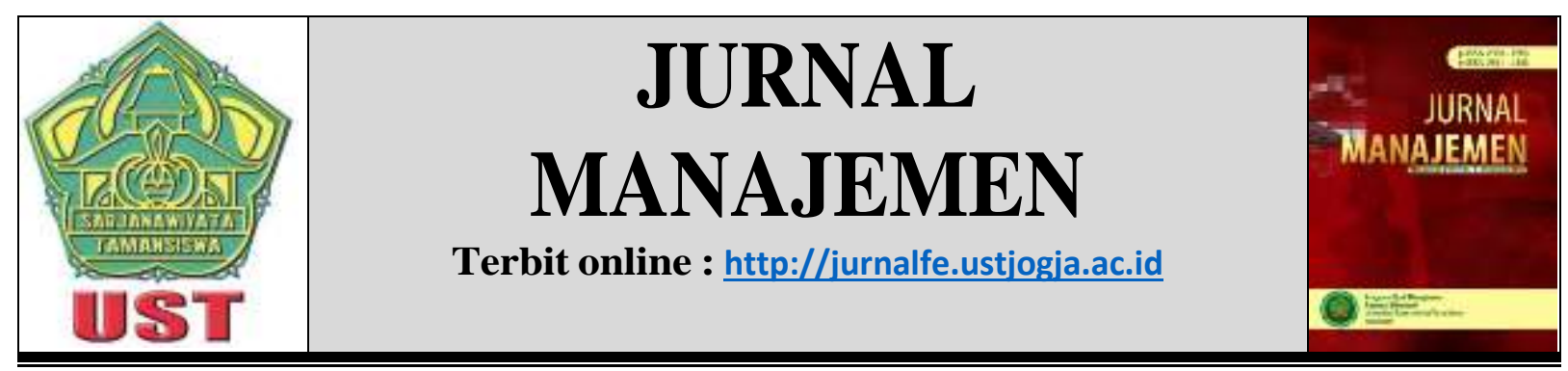

\title{
PERAN MODERASI DIVIDEND PAYOUT RATIO TERHADAP HUBUNGAN PROFITABILITAS DENGAN RETURN SAHAM (STUDI PADA PERUSAHAAN MANUFAKTUR YANG TERDAFTAR DI SEKTOR INDUSTRI BARANG KONSUMSI PERIODE TAHUN 2016-2018)
}

\author{
Nailul Mufidah ${ }^{1}$ \\ Indah Yuliana ${ }^{2}$ \\ 1,2 Program Studi Manajemen, Fakultas Ekonomi, UIN Malang \\ Email: nailulmufidah66@gmail.com
}

\begin{tabular}{l}
\hline Informasi Naskah \\
\hline Diterima: \\
18 November 2019 \\
Revisi: 17 Maret 2020 \\
Terbit: \\
26 Desember 2020 \\
\hline
\end{tabular}

Kata Kunci: stock return, ROA, NPM, DPR

\section{Pendahuluan}

Pasar modal merupakan pasar dimana tempat untuk bertransaksi jual beli beberapa macam instrumen keuangan jangka panjang (saham maupun obligasi) yang diterbitkan oleh pemerintah maupun perusahaan swasta (Husnan, 2001). Saham merupakan salah satu dari instrumen pasar modal yang banyak dikenal dikalangan masyarakat. Saham merupakan bukti penyertaan modal suatu perusahaan maupun bukti kepemilikan atas suatu perusahaan (Fakhruddin, 2008). Perusahaan terbuka (go public) yaitu perusahaan yang menerbitkan sahamnya di pasar modal yang terdiri dari beberapa perusahaan yang dikelompokkan sesuai dengan bidang usahanya kedalam berbagai sektor. 
Dimana masing-masing sektor perusahaan tersebut mempunyai harga saham yang berbeda-beda yang mempengaruhi tingkat returnnya juga ikut berbeda.

Return merupakan salah satu faktor utama yang mempengaruhi keputusan untuk berinvestasi. Menurut Jogiyanto (2007) return saham merupakan hasil yang diperoleh dari berinvestasi. Sedangkan menurut Robert Ang (2001) return saham adalah tingkat keuntungan yang diperoleh oeh pemegang saham atas suatu investasi yang dilakukan. Berdasarkan pengertian yang dikemukakan oleh para pakar diatas dapat disimpulkan bahwa return saham adalah tingkat keuntungan yang diperoleh oleh investor dari hasil investasi saham yang dilakukan. Jika return saham positif berarti keuntungan yang didapatkan dari hasil investasi saham, sebaliknya jika return saham negatif maka kerugian yang diperoleh dari hasil investasi sahamnya. Seorang investor tentu saja akan selalu berusaha agar mendapatkan return saham positif dai hasil investasi yang ia lakukan. Pengukuran return saham dapat dilakukan dengan menghitung perubahan nilai saham suatu periode dengan periode berikutnya. Pengukuran return saham ini digunakan untuk mengetahui kemampuan perusahaan dalam memperoleh keuntungannya.

Objek penelitian yang digunakan dalam penelitian ini yaitu perusahaan-perusahaan manufaktur sektor industri barang konsusmsi periode tahun 2016-2018. Sektor ini dipilih sebagai objek penelitian dikarenakan perusahaan-perusahaan yang ada di sektor tersebut dianggap memiliki peluang bisnis yang cukup tinggi, dan juga prospek industri berbasis konsumsi akan tetap cerah karena permintaan yang tetap tinggi didukung oleh jumlah penduduk yang besar dengan kemampuan daya belinya yang tinggi. Namun, berdasarkan data statistik Badan Pusat Statistik (BPS) Sepanjang Januari-September 2017, pertumbuhan barang konsumsi atau kebutuhan konsumen (Fast Moving Consumer Goods/ FMCG) hanya tumbuh 2,7 persen dibandingkan dengan periode yang sama tahun sebelumnya. Angka ini jauh di bawah rata-rata tahunan yang tumbuh sekitar 11 persen. Masyarakat yang berpenghasilan rendah yang memegang porsi terbesar mengalami penurunan pendapatan yang berdampak pada naiknya harga kebutuhan seperti sewa rumah maupun turunnya uang lembur karena efisiensi perusahaan. Hal ini membuat mereka terpaksa harus menahan dan mengurangi konsumsi barang di luar kebutuhan pokok. Grafik 1 Pertumbuhan Sektor Industri Barang Konsumsi

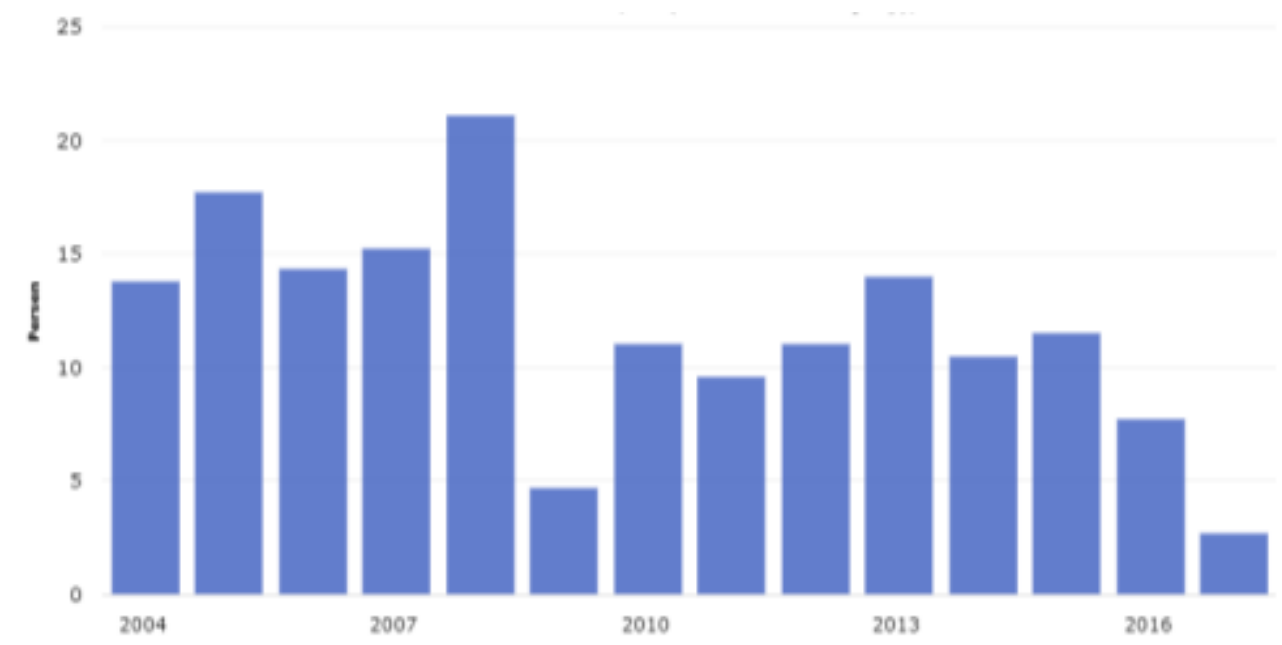

Sumber: Badan Pusat Statistik (2019)

Kinerja rasio keuangan merupakan salah satu dari faktor fundamental, yaitu faktor keuangan perusahaan yang memiliki pengaruh terhadap return saham. Kondisi keuangan perusahaan dapat menggambarkan keberhasilan perusahaan dalam pengelolaannya. Terdapat beberapa rasio keuangan pada analisis fundamental yang dapat mencerminkan kondisi keuangan suatu perusahaan. Brealey et al (2006) membagi rasio keuangan menjadi 4 rasio yaitu rasio leverage, rasio likuiditas, rasio efisiensi, dan rasio profitabilitas. 
Salah satu dari beberapa rasio keuangan yaitu rasio profitabilitas yang digunakan untuk mengukur seberapa besar tingkat keuntungan yang dapat diperoleh oleh perusahaan. Semakin besar tingkat keuntungan yang dihasilkan perusahaan menunjukkan semakin baik manajemen dalam mengelola perusahaan (Sutrisno, 2008). Dalam penelitian ini penulis menggunakan variabel return on asset (ROA) dan net profit margin (NPM) sebagai indikator rasio profitabilitas yang mempengaruhi return saham.

Return On Asset (ROA) merupakan ukuran kemampuan perusahaan dalam menghasilkan keuntungan (return) bagi perusahaan dengan memanfaatkan aktiva yang dimilikinya (Ang, 1997). Beberapa hasil penelitian yang meneliti mengenai pengaruh return on asset (ROA) terhadap return saham antara lain penelitian yang dilakukan oleh Guntur (2013), Anis Sutriani (2014), Ria Veronica (2017), Andy Prasetyo (2018), Novita dan Endang (2019) menemukan bahwa ROA tidak berpengaruh signifikan terhadap return saham. Sebaliknya Ulupui (2007), Farkhan, Ika (2013), Pandu Dewanthoro (2014), Gd Gilang dan I Ketut Wijaya (2015), Umi Solikhah (2015), Ferdinan dan Paulus (2016), Ihsan, dkk (2017), Isnaini, dkk (2017), Yuni, dkk (2017), Ratna dan Noer (2018), Nisrina Huwaida (2019), Ria Veronica (2019), menemukan bahwa ROA berpengaruh positif dan signifikan terhadap return saham.

Net Profit Margin (NPM) merupakan rasio antara laba bersih (net profit) yaitu penjualan sesudah pajak dikurangi dengan seluruh biaya termasuk pajak dibandingkan dengan penjualan. Semakin tinggi net profit margin, semakin baik pula operasi suatu perusahaan (Syamsuddin, 1994). Beberapa hasil penelitian yang meneliti mengenai pengaruh NPM terhadap harga saham menunjukkan hasil yang berbeda antara satu dengan yang lainnya. Hasil penelitian Ferdinan dan Paulus (2016), menunjukkan bahwa NPM berpengaruh signifikan terhadap return saham, sebaliknya hasil penelitian Dedi Aji (2012), Pandu Dewanthoro (2014), Umi Solikhah (2015), Mohamad Zulman dan Dirvi (2018), Rosmiati Tarmizi, dkk (2018) Santi Warwati Simanjuntak, dkk (2019) menunjukkan bahwa NPM tidak berpengaruh signifikan terhadap return saham.

Berdasarkan hasil fenomena gap tersebut, ditemukan hasil yang berbeda-beda mengenai pengaruh return on asset dan net profit margin terhadap return saham. Di satu sisi variabel tersebut memiliki pengaruh yang signifikan terhadap return saham, namun di sisi lain variabel tersebut tidak memiliki pengaruh yang signifikan terhadap return saham. Berdasarkan perbedaan hasil penelitianpenelitian tersebut dapat disimpulkan bahwa tidak ada keselarasan dalam penelitian tersebut.

Selain terdapat hubungan langsung antara variabel independen dengan variabel dependen dalam suatu penelitian juga kemungkinan terdapat pengaruh dari variabel-variabel lain. Salah satu variabel lainnya adalah variabel moderating. Variabel moderating merupakan suatu jenis variabel yang memiliki kemampuan dalam memperkuat maupun memperlemah suatu hubungan secara langsung yang terjadi antara variabel independen dengan variabel dependen. Dalam penelitian ini penulis menggunakan kebijakan deviden sebagai variabel moderating yang diproksikan dengan dividend payout ratio (DPR) yang masih jarang dilakukan oleh peneliti yang lain.

\section{KAJIAN PUSTAKA DAN HIPOTESIS}

Return saham adalah tingkatan keuntungan yang dinikmati oleh pemegang saham atas suatu investasi saham yang dilakukan (Ang, 1997). Setiap investasi baik jangka pendek maupun jangka panjang mempunyai tujuan utama untuk mendapatkan keuntungan yang disebut return baik langsung maupun tidak langsung (Ang, 1997). Tandelilin (2001) menyatakan bahwa sumbersumber return investasi terdiri dari dua unsur utama yaitu yield dan capital gain/loss. Yield merupakan unsur return yang mencerminkan aliran kas atau pendapatan yang diperoleh secara periodik dari suatu investasi. Yield ditunjukkan oleh besarnya dividen yang diperoleh. Sedangkan capital gain/loss sebagai unsur kedua dari return yang merupakan kenaikan/ penurunan harga suatu surat berharga (bisa saham maupun surat utang jangka panjang), yang bisa memberikan keuntungan/kerugian bagi investor. Dalam kata lain, capital gain/loss bisa juga diartikan sebagai perubahan harga sekuritas. Dalam penelitian ini, peneliti hanya menggunakan perhitungan return saham dalam selisih harga saham atau yang dikenal sebagai capital gain/loss. 
Rasio profitabilitas merupakan rasio yang bertujuan untuk mengetahui kemampuan perusahaan dalam menghasilkan laba selama periode tertentu dan tingkat efektifitas manajemen dalam melaksanakan kegiatan operasinya. Efektifitas manajemen dapat dilihat dari laba yang dihasilkan terhadap penjualan dan investasi perusahaan. Rasio ini disebut juga rasio rentabilitas. Keuntungan merupakan hasil dari keputusan yang diambil oleh manajemen. Rasio profitabilitas untuk mengukur seberapa besar tingkat keuntungan yang dapat diperoleh oleh perusahaan. Semakin besar tingkat keuntungan menunjukkan semakin baik manajemen dalam mengelola perusahaan (Sutrisno, 2008). Rasio profitabilitas terdiri dari : return on asset (ROA), return on equity (ROE), net profit margin (NPM), gross profit margin (GPM), return on sales ratio (ROS), return on capital employed (ROCE), return on investment (ROI), earning per share (EPS).

\section{Pengaruh Return On Asset (ROA) terhadap Return Saham}

Return On Asset merupakan rasio perbandingan antara laba bersih dengan total aktiva dalam menghasilkan laba. Kasmir (2012:201) menjelaskan bahwa Return On Asset adalah rasio yang menunjukkan hasil pengembalian dari total aktiva yang digunakan dalam perusahaan. Dapat pula diartikan bahwa Return On Asset (ROA) merupakan rasio yang menunjukkan banyaknya laba bersih yang bisa diperoleh dari semua asset yang dimiliki oleh perusahaan. Setiap perubahan pada nilai ROA mengakibatkan perubahan yang positif dan signifikan pada nilai Return Saham. Semakin tinggi nilai ROA, artinya semakin besar kemampuan perusahaan memperoleh keuntungan dari aset yang dimiliki akan mempengaruhi tingkat pengembalian terhadap para pemegang saham, sehingga akan mempengaruhi harga saham yang berpengaruh terhadap return saham. (Pandhu, 2014)

Farkhan dan Ika (2013) menyebutkan bahwa nilai perusahaan ditentukan oleh earning power dari aktiva perusahaan. Akan tetapi hasil yang positif menunjukan bahwa semakin tinggi erning power maka akan semakin tinggi pula tingkat efisiensi perputaran aktiva dan semakin tinggi pula profit margin yang diperoleh oleh perusahaan, yang akan berdampak pada peningkatan nilai perusahaan dan mengakibatkan return saham meningkat. Para investor masih menggunakan Return On Assets (ROA) sebagai tolak ukur kinerja perusahaan yang digunakan untuk memprediksi total return saham, dengan demikian Return On Assets (ROA) yang semakin besar akan menunjukan kinerja perusahaan naik sehingga return saham juga akan naik.

H1: Return On Asset berpengaruh positif dan signifikan terhadap return saham

\section{Pengaruh Net Profit Margin (NPM) terhadap Return Saham}

Riyanto (2001:39) menyatakan bahwa besar kecilnya net profit margin pada setiap aktivitas penjualan disebabkan oleh 2 faktor, yaitu net sales dan laba usaha. Besar kecilnya laba usaha tergantung pada jumlah pendapatan dari penjualan (sales) dan besarnya biaya usaha (operating expenses). Jika nilai NPM semakin meningkat berarti kinerja perusahaan semakin membaik serta keuntungan yang diperoleh pemegang saham akan semakin meningkat. Peningkatan pada Net Profit Margin (NPM) akan berdampak pada peningkatan return saham pada perusahaan, dan penurunan pada nilai Net Profit Margin (NPM) akan berdampak pada penurunan return saham perusahaan (Ferdinan, 2016).

Dedi Aji (2012) menyebutkan bahwa alasan net profit margin tidak berpengaruh terhadap return saham disebabkan karena naik turunnya data NPM yang digunakan dalam penelitian, selain itu perusahaan tidak mampu dalam menghasilkan keuntungan (laba), sehingga mempengaruhi investor maupun calon investor untuk melakukan investasi pada perusahaan tersebut. Dalam penelitian yang dilakukan oleh Ferdinan Eka Putra dan Paulus Kindangen (2016), menyatakan bahwa Net Profit Margin (NPM) 8 memiliki pengaruh yang signifikan terhadap return saham. Berdasarkan uraian mengenai pengaruh net profit margin (NPM) terhadap return saham, maka dapat dirumuskan hipotesis dalam penelitian ini sebagai berikut:

H2: Net Profit Margin (NPM) berpengaruh positif dan signifikan terhadap return saham. 


\section{Moderasi Pembayaran Dividen Terhadap Profitabilitas Dan Return Saham}

Dividen merupakan salah satu dari bagian laporan keuangan yang mana digunakan perusahaan untuk membagikan keuntungannya pada pemegang saham. Ketika perusahaan membagi dividen pada saat akhir periode laporan keuangan, para pemegang saham akan mendapatkan keuntungan berdasarkan jumlah saham yang dimilikinya. Dividen Payout Ratio yaitu merupakan rasio pembayaran dividen dengan melalui perhitungan dividen kas yang digunakan dibagi dengan laba yang tersedia untuk pemegang saham umum (Hartono, 1998). Apabila sebuah perusahaan mengurangi pembagian dividen, itu dianggap pertanda buruk karena perusahaan banyak membutuhkan pendanaan. Menurut Indriyo dan Basri (2012: 232), Dividen Payout Ratio adalah perbandingan antara dividen yang dibayarkan dengan laba bersih yang didapatkan perusahaan dan biasanya disajikan dalam bentuk prosentase. Bagi investor semakin tinggi rasio pembayaran dividen, maka semakin banyak keuntungan yang akan diterima, akan tetapi perusahaan juga dapat melemahkan posisi keuangan karena dapat mengurangi laba ditahan. Sebaliknya, jika dividen dengan rasio pembayaran yang rendah akan membahayakan pemegang saham, tetapi keuangan internal perusahaan akan tetap diperkuat (Luh Putu dan Ni Luh Sari, 2014)

H3: Pembayaran dividen (dividend payout ratio) memoderasi hubungan profitabilitas dengan return saham

\section{Kerangka Pemikiran}

Faktor-faktor fundamental yang mempengaruhi return saham menurut Samsul (2015, p.200) terdiri atas faktor makroekonomi dan faktor mikroekonomi. Faktor makroekonomi merupakan faktor yang berada di luar perusahaan yang berpengaruh terhadap kenaikan atau penurunan kinerja perusahaan baik secara langsung maupun tidak langsung. Faktor makroekonomi terdiri dari tingkat bunga umum, tingkat inflasi, peraturan perpajakan, kebijakan pemerintah, kurs valuta asing, tingkat bunga pinjaman luar negeri, ekonomi internasional, siklus ekonomi, paham ekonomi, dan peredaran uang. Perubahan dalam faktor makroekonomi akan mempengaruhi kinerja perusahaan dalam jangka waktu yang panjang. Sedangkan faktor mikroekonomi yang mempunyai pengaruh terhadap return saham berada di dalam perusahaan itu sendiri yang tercermin dari laporan keuangan yang secara rutin diterbitkan oleh emiten termasuk kinerja keuangan perusahaan. Kinerja keuangan perusahaan tersebut salah satunya yaitu profitabilitas. Rasio profitabilitas bisa diukur dengan menggunakan rasio keuangan, diantaranya yaitu return on asset (X1) dan net profit margin (X2), yang mempengaruhi return saham (Y). Di samping itu juga terdapat variabel moderating yaitu dividend payout ratio $(\mathrm{Z})$ yang memperkuat atau memperlemah pengaruh variabel independen terhadap return saham.

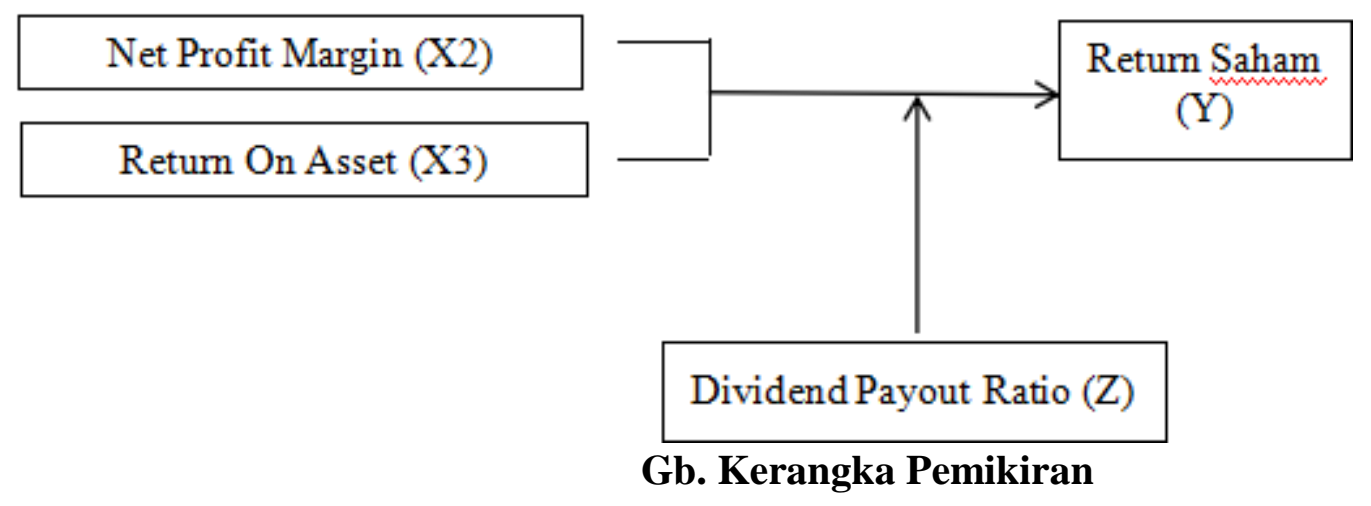

\section{METODE PENELITIAN}

Penelitian ini menggunakan jenis data sekunder yang diperoleh dari Bursa Efek Indonesia (Indonesia Stock Exchange / IDX), Yahoo Finance, dan sumber-sumber lainnya. Populasi dan Sampel Populasi dalam penelitian ini adalah laporan keuangan perusahaan-perusahaan manufaktur 
yang terdaftar dalam sektor industri barang konsumsi periode tahun 2016-2018. Metode penentuan sampel dengan menggunakan purposive sampling yaitu teknik penentuan sampel dengan pertimbangan tertentu. Kriteria penentuan sampel sebagai berikut:

1. Perusahaan tersebut terdaftar di Bursa Efek Indonesia (BEI) sektor industri barang konsumsi selama tahun 2016 sampai tahun 2018

2. Perusahaan memiliki data laporan keuangan lengkap serta mencakup informasi terkait lainnya yang dibutuhkan dalam penelitian ini.

3. Perusahaan menerbitkan laporan keuangan audited selama periode pengamatan dari tahun 2016 sampai tahun 2018.

4. Perusahaan yang membagikan dividen secara konsisten selama tahun 2016-2018.

Tabel 1 Sampel Penelitian

\begin{tabular}{lll}
\hline No & Nama Perusahaan & Kode Saham \\
\hline 1. & Wilmar Cahaya Indonesia Tbk & CEKA \\
2. & Chitose Internasional Tbk & CINT \\
3. & Gudang Garam Tbk & GGRM \\
4. & Indofood CBP Sukses Makmur Tbk & ICBP \\
5. & Indofood Sukses Makmur Tbk & INDF \\
6. & Kino Indonesia Tbk & KINO \\
7. & Kalbe Farma Tbk & KLBF \\
8. & Merck Tbk & MERK \\
9. & Mayora Indah Tbk & MYOR \\
10. & Nippon Indosari Corpindo Tbk & ROTI \\
11. & Mandom Indonesia Tbk & TCID \\
12. & Tempo Scan Pacific Tbk & TSPC \\
13. & Ultra Jaya Milk Industry Tbk & ULTJ \\
\hline
\end{tabular}

Sumber: data sekunder yang diolah

Penelitian ini pengujian hipotesis menggunakan pendekatan Partial Least Square (PLS) 6.0 untuk menganalisis data. PLS adalah metode alternatif untuk menguji persamaan struktual (Struktual Equation Modelling) yang berbasis komponen atau varian (Imam Ghazali, 2014). Alat uji Partial Least Square (PLS) dipilih karena didasarkan pada kerangka pemikiran penelitian yang menguji hubungan yang kompleks dengan banyak variabel dan banyak indikator. Analisis Partial Least Square digunakan untuk mengetahui arah hubungan net profit margin (NPM), return on asset (ROA) terhadap return saham pada perusahaan yang terdaftar dalam sektor industri barang konsumsi periode tahun 2016-2018. Analisis ini juga digunakan untuk mendapatkan koefisien yang akan menentukan apakah hipotesis yang dibuat akan diterima atau ditolak. Analisis Regresi Moderasi digunakan untuk menguji variabel devidend payout ratio dalam memoderasi pengaruh profitabilitas terhadap return saham.

\section{Devinisi Operasional Variabel}

Tabel 2 Devinisi Operasional Variabel

\begin{tabular}{|c|c|c|c|}
\hline Variabel & $\begin{array}{c}\text { Devinisi } \\
\text { Operasional }\end{array}$ & Indikator & $\begin{array}{c}\text { Skala } \\
\text { Pengukuran }\end{array}$ \\
\hline $\begin{array}{l}\text { Return on } \\
\text { asset (X1) }\end{array}$ & $\begin{array}{l}\text { Sejauh mana } \\
\text { kemampuan aset-aset } \\
\text { yang dimiliki } \\
\text { perusahaan bisa } \\
\text { menghasilkan laba } \\
\text { (Tandelilin, }\end{array}$ & $\frac{\text { Laba bersih setelah pajak }}{\text { Total aktiva }} \times 100 \%$ & Rasio \\
\hline
\end{tabular}




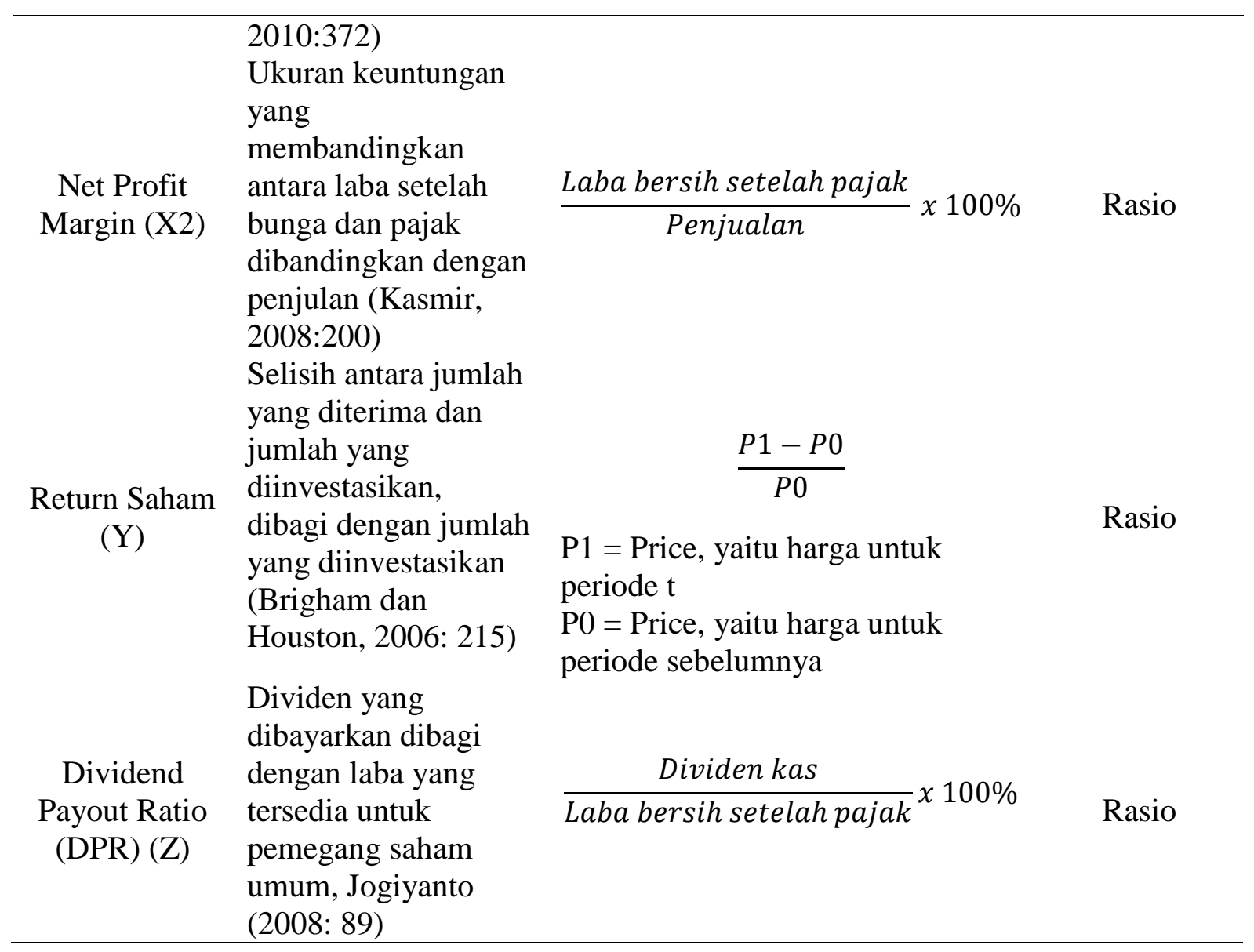

\section{HASIL DAN PEMBAHASAN}

Statistik Deskriptif

Berikut hasil data statistik deskriptif:

Tabel 3 statistik deskriptif

Descriptive Statistics

\begin{tabular}{lrrrrrr}
\hline & \multicolumn{2}{c}{ N } & \multicolumn{2}{c}{ Minimum } & Maximum & \multicolumn{2}{c}{ Mean } & Std. Deviation \\
& Statistic & Statistic & Statistic & Statistic & Std. Error & \multicolumn{1}{c}{ Statistic } \\
\hline ROA & 39 & 2.61 & 20.60 & 9.7590 & .73904 & 4.61532 \\
NPM & 39 & 2.52 & 15.10 & 8.2623 & .52327 & 3.26780 \\
RETURN & 39 & -.49 & 1.00 & .0831 & .04257 & .26585 \\
SAHAM & 39 & 10.69 & 79.03 & 37.5264 & 2.63950 & 16.48365 \\
DPR & 39 & & & & & \\
Valid N (listwise) & 39 & & & &
\end{tabular}

Sumber: Data diolah (2019)

Hasil tabel 3 menunjukkan bahwa jumlah sampel yang diambil dalam penelitian ini sebanyak 39 sampel. Dari 39 sampel ini menunjukkan bahwa Variabel ROA (X1) memiliki nilai rata-rata sebesar 9,7590, nilai maksimum 20,60, dan nilai minimum 2,61. Variabel NPM (X2) memiliki nilai rata-rata sebesar 8,2623 , nilai maksimum 15,10 , dan nilai minimum 2,52. Variabel Return Saham (Y) memiliki nilai rata-rata sebesar 0,0831, nilai maksimum 1,00, dan nilai minimum -0,49. Variabel DPR (Z) memiliki nilai rata-rata sebesar 37,5264, nilai maksimum 79,03, dan nilai minimum 10,69. 


\section{Evaluasi Outer Model}

Uji validitas digunakan untuk menguji suatu variabe penelitian, apakah indikator-indikator yang digunakan dapat membenarkan model variabel dari sebuah penelitian. Output dari program WarpPLS yaitu loading factors dan cross loadings yang digunakan untuk menunjukkan hasil pengujian validitas konvergen dari suatu alat pengukuran. Menurut Hair, dkk., (2013 dalam Mahfud dan Solihin, 2013:65) terdapat dua kriteria untuk menilai validitas konvergen untuk variabel reflektif, yaitu nilai loading harus $>0,7$ dan nilai $\mathrm{p}$ signifikan $(\mathrm{p}<0,005)$. Kriteria variabel diskriminan yaitu nilai loading factor indikator terhadap variabel harus lebih besar dibandingkan nilai loading factor indikator kepada variabel lainnya.

Tabel 4 Cross Loading

\begin{tabular}{ccccccccc}
\hline Indikator & ROA & NPM & $\begin{array}{c}\text { Return } \\
\text { Saham }\end{array}$ & DPR & $\begin{array}{c}\text { DPR* } \\
\text { ROA }\end{array}$ & $\begin{array}{c}\text { DPR* } \\
\text { NPM }\end{array}$ & SE & P Value \\
\hline ROA & $(1,000)$ & 0,000 & 0,000 & 0,000 & 0,000 & 0,000 & 0,104 & $<0,001$ \\
NPM & 0,000 & $(1,000)$ & 0,000 & 0,000 & 0,000 & 0,000 & 0,104 & $<0,001$ \\
Return & 0,000 & 0,000 & $(1,000)$ & 0,000 & 0,000 & 0,000 & 0,104 & $<0,001$ \\
Saham & & & & & & & & \\
DPR & 0,000 & 0,000 & 0,000 & $(1,000)$ & 0,000 & 0,000 & 0,104 & $<0,001$ \\
DPR*ROA & 0,000 & 0,000 & 0,000 & 0,000 & $(1,000)$ & 0,000 & 0,104 & $<0,001$ \\
DPR*NPM & 0,000 & 0,000 & 0,000 & 0,000 & 0,000 & $(1,000)$ & 0,1 & $<0,001$ \\
\hline
\end{tabular}

Sumber : Data diolah (2019)

Tabel 2 diatas menunjukkan hasil bahwa nilai loading dari ROA, NPM, Return saham, DPR, DPR*ROA, DPR*NPM > 0,7 yaitu 1,000 yang sudah memenuhi kriteria convergent validity. PValue untuk semua indikator juga telah memenuhi syarat yaitu memliki nilai sebesar $<0,05$ yaitu $<$ 0,001 .

Pengukuran lainnya dari convergent validity adalah dengan melihat nilai AVE (Average Variance Extracted). Mahfud Sholihin dan Dwi Ratmono (2013: 73) menyatakan bahwa AVE (Average Variance Extracted) juga digunakan untuk evaluasi validitas konvergen, kriteria yang harus dipenuhi yaitu nilai AVE $>0,50$.

Tabel 5 Uji Validitas Diskriminan

\begin{tabular}{lccl}
\hline \multicolumn{1}{c}{ Variabel } & Nilai AVE & Kriteria & Keterangan \\
\hline ROA & 1,000 & $>0,50$ & Memenuhi convergent validity \\
NPM & 1,000 & $>0,50$ & Memenuhi convergent validity \\
Return saham & 1,000 & $>0,50$ & Memenuhi convergent validity \\
DPR & 1,000 & $>0,50$ & Memenuhi convergent validity \\
DPR*ROA & 1,000 & $>0,50$ & Memenuhi convergent validity \\
DPR*NPM & 1,000 & $>0,50$ & Memenuhi convergent validity \\
\hline
\end{tabular}

Sumber : Data diolah (2019)

Berdasarkan hasil tersebut keempat variabel telah memenuhi convergent validity. Nilai AVE dari ROA, NPM, Return Saham, DPR, DPR*ROA, DPR*NPM yaitu 1,000 >0,50. Kesimpulannya keseluruhan variabel telah memenuhi kriteria convergent validity.

Menurut Ghozali (2012: 79), uji reliabilitas dilakukan untuk menguji dan membuktikan kekonsistenan dan ketepatan instrument dalam mengukur suatu variabel. Uji reliabilitas dilakukan dengan melihat nilai composite reliability dan Cronbach's Alpha. Nilai composite reliability dianggap baik jika nilainya $>0,70$ dan Cronbach's Alpha disarankan diatas 0,60. Sehingga keakurasian suatu variabel dikatakan baik jika nilainya memenuhi kriteria. 
Tabel 6 Hasil Uji Reliabilitas

\begin{tabular}{lccc}
\hline Variabel & $\begin{array}{c}\text { Composite reliability } \\
\text { coefficient }\end{array}$ & Cronbach alpha & Keterangan \\
\hline ROA & 1,000 & 1,000 & Reliabel \\
NPM & 1,000 & 1,000 & Reliabel \\
Return saham & 1,000 & 1,000 & Reliabel \\
DPR & 1,000 & 1,000 & Reliabel \\
DPR*ROA & 1,000 & 1,000 & Reliabel \\
DPR*NPM & 1,000 & 1,000 & Reliabel \\
\hline
\end{tabular}

Sumber : Data diolah (2019)

Berdasarkan hasil perhitungan pada tabel di atas, tampak bahwa ROA, NPM, Return Saham, DPR, DPR*ROA, DPR*NPM memiliki nilai reliabilitas 1,000. Dimana nilai reliabilitas masingmasing variabel dinilai sangat baik karena nilai composite reliability sudah memenuhi syarat $(>0,7)$. Reliabilitas juga dipengaruhi oleh besarnya nilai hasil perhitungan Cronbach Alpha dimana nilai cronbach alpha dari ROA, NPM, Return Saham, DPR, DPR*ROA, DPR*NPM bernilai sebesar 1,000 yang menyatakan bahwa semua variabel telah memenuhi syarat reliabilitas variabel yang baik.

\section{Evaluasi Inner Model}

Pada uji kecocokan model terdapat tiga indeks pengujian, yaitu average path coefficient (APC), average R-squared (ARS) dan averge varians factor (AVIF) dengan kriteria APC dan ARS diterima dengan syarat p-value <0,05 dan AVIF <5 (Mahfud Sholihin dan Dwi Ratmono, 2013:61).

Tabel 7 Hasil Uji Evaluasi Goodness Of Fit

\begin{tabular}{lllll}
\hline Parameter & Indeks & P-Value & Kriteria & Keterangan \\
\hline APC & 0,305 & 0,009 & $\mathrm{P}<0,05$ & Diterima \\
ARS & 0,395 & 0,001 & $\mathrm{P}<0,05$ & Diterima \\
AVIF & 2,027 & & AVIF $<5$ & Diterima \\
\hline
\end{tabular}

Data diolah (2019)

Berdasarkan tabel di atas, menjelaskan bahwa APC memiliki indeks sebesar 0,305 dengan nilai $\mathrm{p}$ - value $<0,009$. Sedangkan ARS memiliki indeks sebesar 0,395 dengan $\mathrm{p}-$ value $<0,001$. Berdasarkan kriteria, APC sudah memenuhi kriteria karena memiliki nilai $\mathrm{p}<0,009$. Begitu pula dengan nilai $\mathrm{p}$ dari ARS yaitu $\mathrm{p}<0,05$. Nilai AVIF yang harus $<5$ sudah terpenuhi karena berdasarkan data tersebut AVIF nilainya 2,027. Dengan demikian, maka inner model dapat diterima

Nilai R-Square harus $>0$ menjadi syarat untuk menunjukkan bahwa nilai observasi dihasilkan oleh model dan estimasi perhitungan seluruh populasi dan sampelnya baik, sebaliknya jika nilai R-Square $\leq 0$ menunjukkan nilai observasi dihasilkan oleh model dan estimasinya kurang baik.

Tabel 8 Hasil Uji Nilai R-Square

\begin{tabular}{lcc}
\hline \multicolumn{1}{c}{ Variabel } & Nilai R-Square & Keterangan \\
\hline ROA & & \\
NPM & 0,395 & $>0,000$ \\
Return saham & & \\
DPR & & \\
DPR*ROA & & \\
DPR*NPM & & \\
\hline
\end{tabular}

Data diolah (2019) 
Berdasarkan tabel di atas menunjukkan bahwa nilai R-Square $>0$ yang berarti bahwa nilai observasi yang dihasilkan oleh model dan estimasi perhitungan seluruh populasi dan sampelnya telah memenuhi syarat, atau telah memenuhi Goodness of Fit yang baik.

\section{Hasil Pengujian Hipotesis dan Pembahasan}

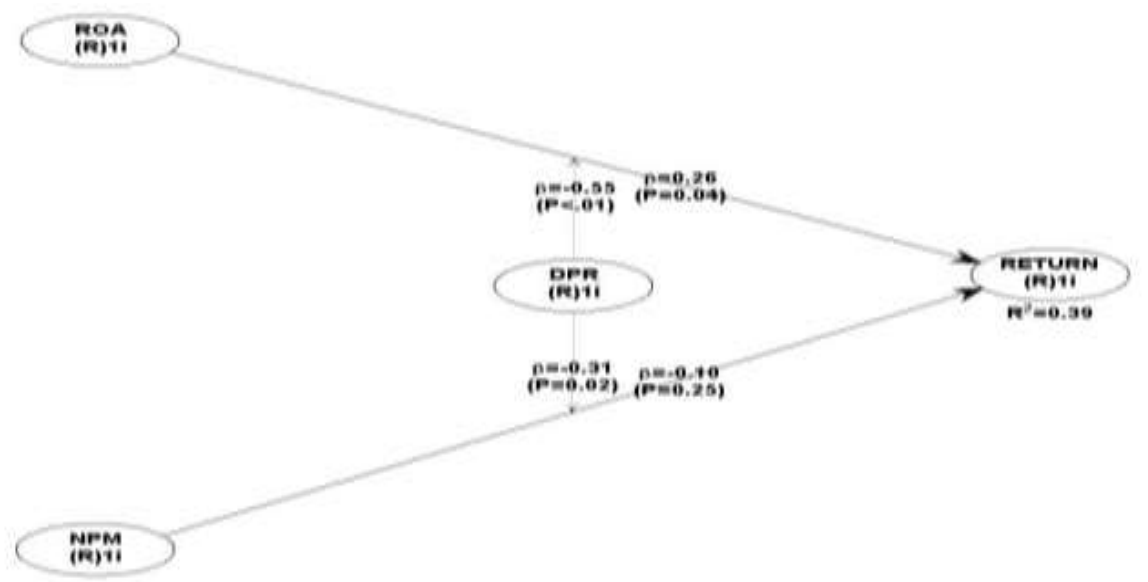

\section{Pengaruh ROA terhadap return saham}

Hipotesis dalam penelitian ini adalah ROA berpengaruh positif dan signifikan terhadap return saham. Setiap perubahan pada nilai ROA mengakibatkan perubahan yang positif dan signifikan pada nilai Return Saham. Berdasarkan hasil uji yang dilakukan dengan WarpPLS 6.0 menunjukkan hasil bahwa nilai koefisien sebesar 0,26 dan nilai signifikan sebesar 0,04 yang < 0,05. Hal ini menjukkan bahwa hipotesis pertama terpenuhi yaitu Return On Asset berpengaruh positif dan signifikan terhadap return saham. Artinya, semakin tinggi nilai ROA, artinya semakin besar kemampuan perusahaan dalam memperoleh keuntungan dari aset yang dimiliki, hal ini tentunya akan mempengaruhi tingkat pengembalian terhadap para pemegang saham, sehingga akan mempengaruhi harga saham yang berpengaruh terhadap return saham. Hal ini sejalan dengan penelitian yang dilakukan oleh Farkhan dan Ika (2013) yang menyebutkan bahwa Para investor masih menggunakan Return On Assets (ROA) sebagai tolak ukur kinerja perusahaan yang digunakan untuk memprediksi total return saham, dengan demikian Return On Assets (ROA) yang semakin besar akan menunjukan kinerja perusahaan naik sehingga return saham juga akan naik. Hasil penelitian ini membuktikan bahwasemakin tinggi nilai ROA maka nilai return saham akan naik, sebaliknya jika nilai ROA turun sebesar maka nilai return saham akan turun.

\section{Pengaruh NPM terhadap return saham}

Hipotesis dalam penelitian ini adalah NPM berpengaruh positif dan signifikan terhadap return saham. Semakin tinggi net profit margin, semakin baik pula operasi suatu perusahaan. (Ferdinan, 2016) membuktikan bahwa semakin meningkatnya nilai NPM berarti kinerja perusahaan semakin baik serta keuntungan yang diperoleh pemegang saham akan semakin meningkat yang akan berdampak pada peningkatan return saham perusahaan, dan penurunan pada nilai Net Profit Margin (NPM) akan berdampak pada penurunan return saham perusahaan.

Berdasarkan hasil uji yang dilakukan dengan WarpPLS 6.0 menunjukkan hasil bahwa nilai koefisien sebesar $-0,10$ dan nilai signifikan sebesar 0,25 yang > 0,05. Hasil penelitian ini tidak berhasil membuktikan hipotesis kedua yang menyatakan bahwa NPM berpengaruh terhadap return saham pada perusahaan sektor industri barang konsumsi yang terdaftar di BEI. Artinya, variabel Net Profit Margin (NPM) tidak berpengaruh terhadap return saham disebabkan karena adanya naik turunnya nilai NPM pada data yang digunakan dalam penelitian dan perusahaannya pun tidak mampu dalam menghasilkan keuntungan (laba), sehingga mempengaruhi investor maupun calon 
investor untuk melakukan investasi. Keadaan yang terjadi saat itu adalah investor tidak mau membeli saham dengan harga tinggi dengan nilai Net Profit Margin (NPM) perusahaan yang rendah, akibatnya Net Profit Margin (NPM) tidak mempengaruhi tingkat return pada perusahaan tersebut. Penelitian ini sejalan dengan penelitian yang dilakukan oleh Dedi Aji (2012).

\section{Pembayaran Dividen (Dividend Payout Ratio) Memoderasi Hubungan Profitabilitas Dengan Return Saham}

Hipotesis dalam penelitian ini adalah devidend payout ratio (DPR) dapat memperkuat pengaruh positif profitabilitas terhadap return saham pada perusahaan sektor industri barang konsumsi. Semakin besar devidend payout ratio, artinya perusahaan memang mengalokasikan keuntungannya untuk para pemegang sahamnya. Sebaliknya jika rasio ini makin kecil, artinya perusahaan mengalokasikan sebagian laba bersihnya untuk memenuhi kebutuhan internal perusahaan.

Berdasarkan hasil uji yang dilakukan dengan WarpPLS 6.0 menunjukkan hasil bahwa nilai koefisien dari DPR* ROA sebesar 0,55 dan nilai signifikan sebesar $<0,01$ yang kurang dari 0,05, sedangkan nilai koefisisen dari DPR*NPM sebesar 0,31 dan nilai signifikan sebesar 0,02 . Artinya, hasil penelitian ini membuktikan bahwa devidend payout ratio dapat memperkuat pengaruh positif profitabilitas terhadap return saham. Semakin tinggi rasio pembayaran dividen bagi investor maka semakin banyak keuntungan yang akan diterimanya, akan tetapi perusahaan pun juga dapat melemahkan posisi keuangan karena dapat mengurangi laba ditahan. Sebaliknya, jika dividen dengan rasio pembayaran yang rendah akan membahayakan pemegang saham, tetapi keuangan internal perusahaan akan diperkuat.

\section{KESIMPULAN}

Kesimpulan dari penelitian ini adalah ROA berpengaruh positif dan signifikan terhadap return saham. Artinya, semakin tinggi nilai ROA, artinya semakin besar kemampuan perusahaan dalam memperoleh keuntungan dari aset yang dimiliki, hal ini tentunya akan mempengaruhi tingkat pengembalian terhadap para pemegang saham, sehingga akan mempengaruhi harga saham yang berpengaruh terhadap return saham. Sedangkan NPM tidak berpengaruh terhadap return saham disebabkan karena adanya naik turunnya nilai NPM pada data yang digunakan dalam penelitian dan perusahaan tidak mampu dalam menghasilkan keuntungan (laba), sehingga mempengaruhi investor maupun calon investor untuk melakukan investasi. Selain itu, DPR mampu memoderasi hubungan profitabilitas terhadap return sham. Semakin besar devidend payout ratio, artinya perusahaan memang mengalokasikan keuntungannya untuk para pemegang sahamnya. Sebaliknya jika rasio ini makin kecil, artinya perusahaan mengalokasikan sebagian laba bersihnya untuk memenuhi kebutuhan internal perusahaan. Keterbatasan dalam penelitian ini adalah penggunaan indikator pada profitabilitas masih menggunakan ROA dan NPM saja. Saran untuk penelitian selanjutnya adalah penambahan pada indikator profitabilitas seperti return on equity (ROE), gross profit margin (GPM), return on sales ratio (ROS), return on capital employed (ROCE), return on investment (ROI), earning per share (EPS). Selain itu, penelitian perlu memperluas dengan beberapa sektor perusahaan di Indonesia.

\section{DAFTAR PUSTAKA}

Aldo, Michael Carlo. (2014). Pengaruh Return On Equity, Dividend Payout Ratio, Dan Price To Earnings Ratio Pada Return Saham. E-Jurnal Akuntansi Universitas Udayana 7.1 (2014):150164 ISSN: 2302-8556

Ang, Robert. (1997). Buku Pintar Pasar Modal Indonesia, Edisi Pertama, Rineka Cipta, Jakarta.

Brealey, Richard A et al. (2006). Dasar-dasar Manajemen Keuangan Perusahaan Jilid 2. Penerbit Erlangga, Jakarta.

Darmaji, Tjipto dan Fakhrudin. (2011). Pasar Modal di Indonesia Edisi 3. Jakarta: Salemba Empat. Dewanthoro, Pandu. (2014). Analisis Pengaruh Rasio Profitabilitas Terhadap Return Saham 
Perusahaan Sektor Properti \& Real Estate Di Bursa Efek Indonesia. E-journal Universitas Islam Indonesia

Eka, Ferdinan Putra dan Paulus Kindangen. (2016). Pengaruh Return On Asset (ROA), Net Profit Margin (NPM), Dan Earning Per Share (EPS) Terhadap Return Saham Perusahaan Makanan Dan Minuman Yang Terdaftar Di Bursa Efek Indonesia (Periode 2010-2014). EJournal EMBA, Vol.4 No.4 September 2016, Hal. 235-245 ISSN 2303-117

Fakhruddin, Hendy M. (2008). Istilah Pasar Modal A-Z. Jakarta: PT Elex Media Komputindo

Farkhan dan Ika. (2013). Pengaruh Rasio Keuangan Terhadap Return Saham Perusahaan Manufaktur di Bursa Efek Indonesia (Studi Kasus Pada Perusahaan Manufaktur Sektor Food and Beverage). e-Journal Universitas Muhammadiyah Semarang, 9(1), h: 1- 18

Gitosudarmo, Indriyo dan Basri. (2012). Manajemen Keuangan. Edisi 4. Yogyakarta: BPFE.

Gunadi, Gd Gilang dan I Ketut Wijaya Kesuma. (2015). Pengaruh ROA, DER, EPS Terhadap Return Saham Perusahaan Food and 19 Beverage BEI. E-Jurnal Manajemen Unud, Vol.4, No.6, hal: 1636-1647 ISSN: 2302-8912

Hartono, J. (2010). Teori Portofolio dan Analisis Investasi. Edisi keenam. Yogyakarta : BPFE.

Hermawan, Dedi Aji. (2012). Pengaruh Debt to Equity Ratio, Earning Per Share dan Profit Margin Terhadap Return Saham. Management Analysis Journal, 1(5), h: 1-7.

Husnan, Suad. (2001). Dasar-Dasar Teori Portofolio dan Analisis Sekuritas. Yogyakarta: BPFE

IGKA Ulupui. (2007). Analisis Pengaruh Rasio Likuiditas, Leverage, Aktivitas, dan Profitabilitas terhadap Return Saham (Studi pada Perusahaan Makanan dan Minuman dengan Kategori Industri Barang Konsumsi di BEJ). AUDI Jurnal Akuntansi dan Bisnis, Vol. 1, Januari.

Imam Ghozali. (2013). Aplikasi Analisis Multivariate dengan Program IBM SPSS 21. Edisi 7. Semarang : Badan Penerbit Universitas Diponegoro

Jogiyanto H.M. (2007). Teori Portofolio dan Analisa Investasi.Yogyakarta: BPFE. Edisi 5.

Kasmir. (2012). Dasar-dasar Perbankan. Edisi Revisi. Jakarta: PT Rajawali Pers.

Mahfud Sholihin dan Dwi Ratmono. (2013). Analisis SEM-PLS dengan WarpPLS 3.0 Untuk Hubungan Non Linier Dalam Penelitian Sosial dan Bisnis. Yogyakarta: Penerbit ANDI.

Putu, Luh Ratih Nirayanti dan Ni Luh Sari Widhiyani. (2014). Pengaruh Kebijakan Dividen, Debt to Equity Ratio, dan Price Earning Ratio pada Return Saham. E-Jurnal Akuntansi Universitas Udayana 9.3 (2014): 803 ISSN: 2302 - 8556

Riyanto, Bambang. (2008). Dasar-dasar Pembelanjaan Perusahaan. Yogyakarta: BPFE

Samsul, Mohamad. (2015). Pasar Modal \& Manajemen Portofolio (Ed. 2). Jakarta, Indonesia: Erlangga.

Sutriani, Anis. (2014). Pengaruh Profitabilitas, Leverage, Dan Likuiditas Terhadap Return Saham Dengan Nilai Tukar Sebagai Variabel Moderasi Pada Saham LQ-45. Journal of Business and Banking. Volume 4, No. 1, May 2014, pages $67-80$

Sutrisno, (2008). Manajemen Keuangan Teori, Konsep Dan Aplikasi. Yogyakarta: Penerbit Ekonisia.

Tandelilin, Eduardus. (2001). Analisis Investasi dan Manajemen Portofolio, Edisi Pertama. BPFE UGM: Yogyakarta. 